\title{
Development of mentor teacher role inventory
}

\author{
Ebru Melek Koç* \\ Izmir Institute of Technology, Department of Foreign Languages, Izmir, Turkey
}

\begin{abstract}
This study aimed to develop and investigate the validity and reliability of the Mentor Teacher Role Inventory (MTRI). A total of 1843 student teachers in the Distance English Teacher Training Program participated in the study. The 58 items of the Mentor Teacher Role Inventory underwent principal factor analysis, which revealed nine factors relating to mentorship and explained $52.971 \%$ of the total variance. The KMO value of the MTRI was calculated as .968 . The Cronbach's alpha was .951. These results indicated that a reliable and valid MTRI could be used for both the distance English teacher training programme and other distance teacher education programmes.
\end{abstract}

Keywords: student teachers; co-operating teachers; mentors; distance teacher education

\section{Introduction}

The term 'mentor' is rooted in Homer's Greek epic poem 'The Odyssey'. In the poem, King Odysseus gave the responsibility of nurturing his son Telemachus to his loyal friend and advisor Mentor, who was a guiding, supportive and trusted educator. Mentor educated and guided Odysseus' son. This education included every facet of his life including physical, intellectual, spiritual, social and administrative development (Clawson 1980). Since then the word 'mentor' has become synonymous with wise teacher, guide, adviser, sponsor and supporter as well as a friend. Within the research in teacher education, mentoring has many different definitions depending on the context (Merriam 1983; Zanting, Verloop, and Vermunt 2001). In the context of pre-service teacher education context, Anderson and Shannon's definition supports many aspects of mentoring. Therefore, it is used as an underlying definition of 'mentor' in the present study.

According to 'The mentor in Odyssey', Anderson and Shannon (1988) define 'mentoring' as a supportive, nurturing process in which a more skilled/experienced person teaches, sponsors, encourages, counsels, models, and befriends a less skilled/ experienced person for the purpose of promoting the latter's professional and personal development. According to this definition, mentors (e.g., the university and co-operating teachers) are responsible for training the student teachers to be effective. This occurs during the practicum where the mentor is in a key position to influence the learning experience of student teachers and to facilitate an effective supervisory process. In the present study the terms mentor and co-operating teacher, and student teacher and mentee, are used interchangeably.

\footnotetext{
*Email: ebrukoc@iyte.edu.tr 


\section{Background to the study}

The Distance English Teacher Training Program (DETTP) is offered by Anadolu University in the distance education format and was developed in 2000 to solve the national shortage of English language teachers, which Turkey has been facing for years. The DETTP is a four-year programme with a blended learning format in which the student teachers receive face-to-face training in the first two years and distance training during their last two. Face-to-face education is implemented in eight different cities. These cities represent the seven regions of Turkey. During the first two years the student teachers must live in one of these in order to get face-to-face education. During the third and fourth years, the student teachers are educated by distance learning. During the last two years the major source for the student teachers are course books. Computer mediated communication (CMC) is a vital part of the DETTP because most of the courses student teachers take during the third and fourth year are electronically organised to give support and guidance online. The courses are taken annually. For most of the courses the student teachers take three tests at intervals and a final test at the end of the year. For student teachers to pass a particular course, the cumulative average score on all three tests should be 70 . Throughout Turkey, there are 13 test centres. All of the student teachers have to take their tests in one of those centres.

In the final year, the student teachers enrolled in the DETTP take the 'Teaching practice course'. Prior to the practicum, the student teachers are assigned to a state school in the city where they live. The courses at the DETTP are taken annually. The 'Teaching practice course' requires the student teachers to practice teaching under the supervision of a co-operating teacher also called a mentor. The mentor is the subject teacher working at the state school to which the student teacher is assigned. During each week of school, the mentor checks the lessons prior to teaching, observes the student teachers teaching a lesson and writes a review. Then, the mentor concludes the lesson observation with verbal feedback and gives a copy of the written review to be included in the student teacher's portfolio. At the end of each term, the mentor collects the portfolios of the student teachers, grades each portfolio and delivers them to the evaluating committee at Anadolu University.

During the school practice period, it is important for the practicum members to be clear about their own roles as well as each other's. Hall et al. (2008) claim that developing a shared understanding of the mentor's roles/responsibilities can bring greater clarity to the supervisory process. Regarding supervisory roles of the co-operating teachers there are plenty of instruments. For example, Zachary (2000) constructed the 'Mentoring Skills Inventory' to assess mentors' preparation. Podsen and Denmark's (2000) 59-itemed inventory identified eight competency areas of mentors. Rose (2003) developed the 'Ideal Mentor Scale' to study mentoring styles in graduate education. Hall et al. (2005) constructed the 'Mentoring Self-Efficacy Instrument' (MSEI) for primary education. Demirkol (2004) adapted Shippy's investigation of the role expectations of the three members in the practicum to the English language teacher education context in Turkey. Carey and Tullis's (cited in Tullis 1998) 'Student Teacher Expectation Scale' was constructed to determine the student teachers' expectations of the role of the co-operating teacher.

All these instruments regarding the mentor roles are appropriate for traditional pre-teacher education which is implemented in the face-to-face format. On the other hand, there is comparatively less information available regarding an inventory 
associated with cooperating teachers supervising student teachers during distance practicum. The only study of distance English teacher training pre-teacher education is the 'Co-operating Teacher Role Inventory' constructed by Koc (2008). It sought to find out the perceptions of the co-operating teachers about their roles as mentors. To develop a shared understanding of the mentor's responsibilities, it is important to investigate the student teachers' perceptions and categorise the mentor roles from it. Hence, the primary purpose of the present research is to investigate the perceptions of the student teachers regarding mentor roles and create a reliable Mentor Teacher Role Inventory (MTRI) for a distance ELT context.

\section{Conceptual framework}

Hudson's (2004) five-factor model for mentoring that complements constructivism is the conceptual framework of the present study. According to this model, a significant role of the mentor is to display positive 'personal attributes', which involves being constructive, supportive and encouraging. According to this model, another responsibility of the mentor is to provide students with information about technical aspects of teaching. The mentor's 'pedagogical knowledge' of planning, classroom management, teaching strategies, and assessment skills can provide student teachers with a deeper understanding of teaching practice and this 'sharing the knowledge of teaching' helps them make connections between what student teachers have learnt so far in university classes and what they observe in the co-operating schools. In addition, the mentors need to be familiar with the system requirements. Mentors' knowledge of the current English curriculum enables student teachers to achieve a planned and qualified teaching practice. 'Modelling' of mentors also helps the student teachers develop their teaching. Mentors are experts who can model effective teaching (Barab and Hay 2001). Mentors are expected to mould the student teacher to enable him/her to observe routines and ways of managing the class as well as teaching techniques (Hudson and Skamp 2001, 2003). Lastly, the mentor's other important role is providing 'feedback' on the student teachers' lesson plans and observed practices. Mentors are expected to make observations of the student teachers in the classrooms teaching lessons, make comments concerning the lessons and give constructive feedback to them. Following the observation of the teaching performance, how to give feedback to the student teacher is seen as a crucial element in mentoring (Fish 1995).

\section{Method}

In this section the methodology of the study is described. Detailed information about the participants, data collection instrument, data collection procedures and analysis are stated below.

\section{Participants}

In 2007, the number of fourth-year student teachers at the DETTP was 2463. These student teachers were in their final year and enrolled in the 'School Experience II and teaching practice' course in the DETTP at Anadolu University, Open Faculty. Of these, 1843 student teachers, constituting $82.87 \%$ of the total student teacher population, participated in the study. 


\section{Instruments}

The initial aim of this study was to develop a valid and reliable instrument that focused on the perceptions of the student teachers regarding their co-operating teachers' mentoring roles. It used a list constructed in an initial study of 58 items characterising mentor behaviour (Koc 2008). The respondents were asked to indicate how often their co-operating teachers implemented these behaviours. Ratings were made on a five-point Likert scale: ' 1 ' is assigned to 'never', '2' to 'rarely', '3' to 'sometimes', '4' to 'often', and '5' to 'always'.

\section{Procedure}

In 2007 there were 2463 student teachers assigned to 112 co-operating schools in 74 Turkish cities. The Mentor Teacher Role Inventory MTRI was posted in an envelope to each student teacher. Each envelope was placed with another stamped envelope addressed to the researcher for free return of the questionnaires to the researcher. When the data were collected, the student teachers had taught for nearly 11 weeks. When the data were collected, they were given back to the researcher. Of 2463 student teachers, 1846 completed the MTRI.

\section{Results}

Prior factor analysis and the suitability of the data for factor analysis were assessed. The first concern was sample size. Kass and Tinsley (1979) suggest having between 5 and 10 subjects per item on the scale up to a total of 300 . If the number reaches up to 300 , test parameters tend to be stable regardless of the subject to variable ratio. Field (2000) and Tabachnick and Fidell (1996) agree that it is appropriate to have at least 300 cases for factor analysis. Finally, Comrey and Lee (1992) believe that 100 is a poor sample size, 300 can be considered good, and 1000 or more is excellent. Based on this, the current data have an excellent sample size. The student teacher sample $(N=1846)$ included at least 32 times more participants than the number of items, which was far better than the values suggested by Comrey and Lee (1992), Kass and Tinsley (1979), Field (2000) and Tabachnick and Fidell (1996).

Although the sample size was excellent the suitability of the data for factor analysis was conducted as suggested by Pallant (2001). Kaiser-Meyer-Oklin's test and Barlett's test of sphericity are regularly used to determine whether factor analysis is suitable for a particular set of data (Comrey and Lee 1992; Tabachnick and Fidell 1996). Firstly, the Kaiser-Meyer-Oklin Measure of Sampling Adequacy is calculated. The KMO value of the MTRI was calculated as .968. The KMO measure can range between 0 and 1 . Smaller values point to a weak relationship between items making the data inappropriate for factor analysis; Pallant (2001) claims that the KMO statistic should be larger than 0.6. According to Hutcheson and Sofroniou (1999), values between 0.5 and 0.7 are normal, values between 0.7 and 0.8 are good, values between 0.8 and 0.9 are great, and values above 0.9 are superb. Secondly, Bartlett's Test of Sphericity was calculated. A chi-square value $\left(\chi^{2}=31061.737\right)$ with a significance value of .005 meant that the factorability of the correlation matrix was proper. The KMO and Barlett's test of sphericity indicated that the data were suitable for factor analysis. Because it is more popular in the research area and easier to interpret, the principal component was applied as the extraction method (Pallant 2001). 
The 58 items of the MTRI were examined through principal component analysis using SPSS 15.0 for Windows. The principal component analysis revealed the presence of nine factors with eigenvalues exceeding 1 . This explained $31.2 \%, 4.3 \%, 3.3 \%, 3.1 \%$, $2.3 \%, 2.2 \%, 2.1 \%, 2.1 \%$ and $1.9 \%$ of the variance, respectively. An inspection of the scree plot revealed a clear break after the ninth component (see Table 1). The ninecomponent solution explained $52.501 \%$ of the total variance. The eigen values and the scree plot of the nine components are provided in Figure 1. Items with very close loadings (i.e., less than.01) under different components were suppressed from the analysis to prevent multicollinearity. Thus, the 17th, 31st, 39th and 58th questions were deleted.

As mentioned above, nine factors were determined. Because the varimax rotation solution is easily interpreted and provides relatively clear information about which items correlate most strongly with a given factor (Tabachnick and Fidell 1996), they are rotated through a varimax rotation for interpretation.

There are studies claiming that the limit for factor loadings should be between 0.30 and 0.40 (Coombs and Schroeder 1988; Dunteman 1989). Pallant (2001) claims that if an item has a load above 0.3, this is an appropriate loading. Field (2000) suggests that loadings less than 0.4 be suppressed in the output. Similarly, in the present research, 0.40 was taken as the limit to create robust and conservative results, and most items had loadings above 0.4. Item loadings less than 0.40 were not taken into consideration. The 34th, 49th, 55th, 56th and 57th questions had particularly low corrected-item total values, which revealed that those items did not serve the purpose of the current study's data collection tool (i.e., .076, .212, .228, -.174, and .182, respectively).

The 49 total items determined to reliably indicate factors in the scale meant that nine questions were eliminated from the questionnaire. The Cronbach's alpha was

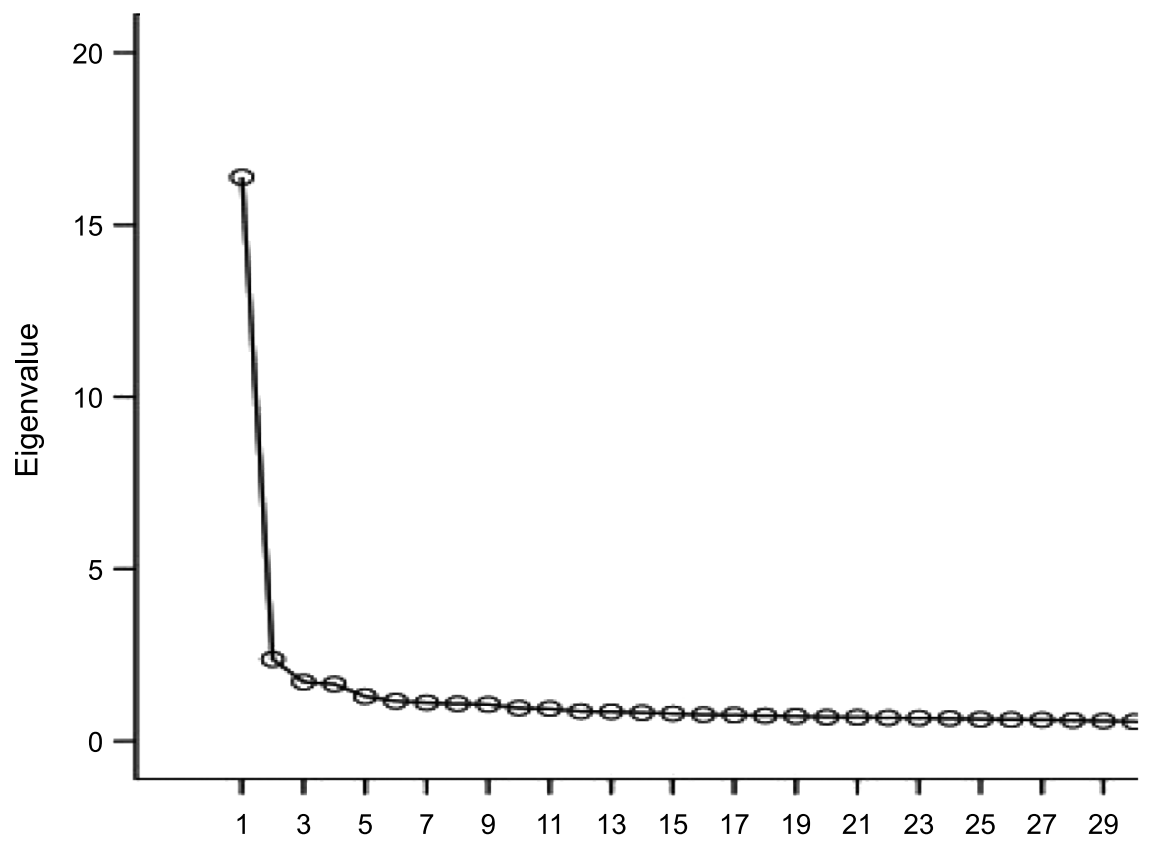

Figure 1. The screeplot regarding factor analysis of MTRI. 


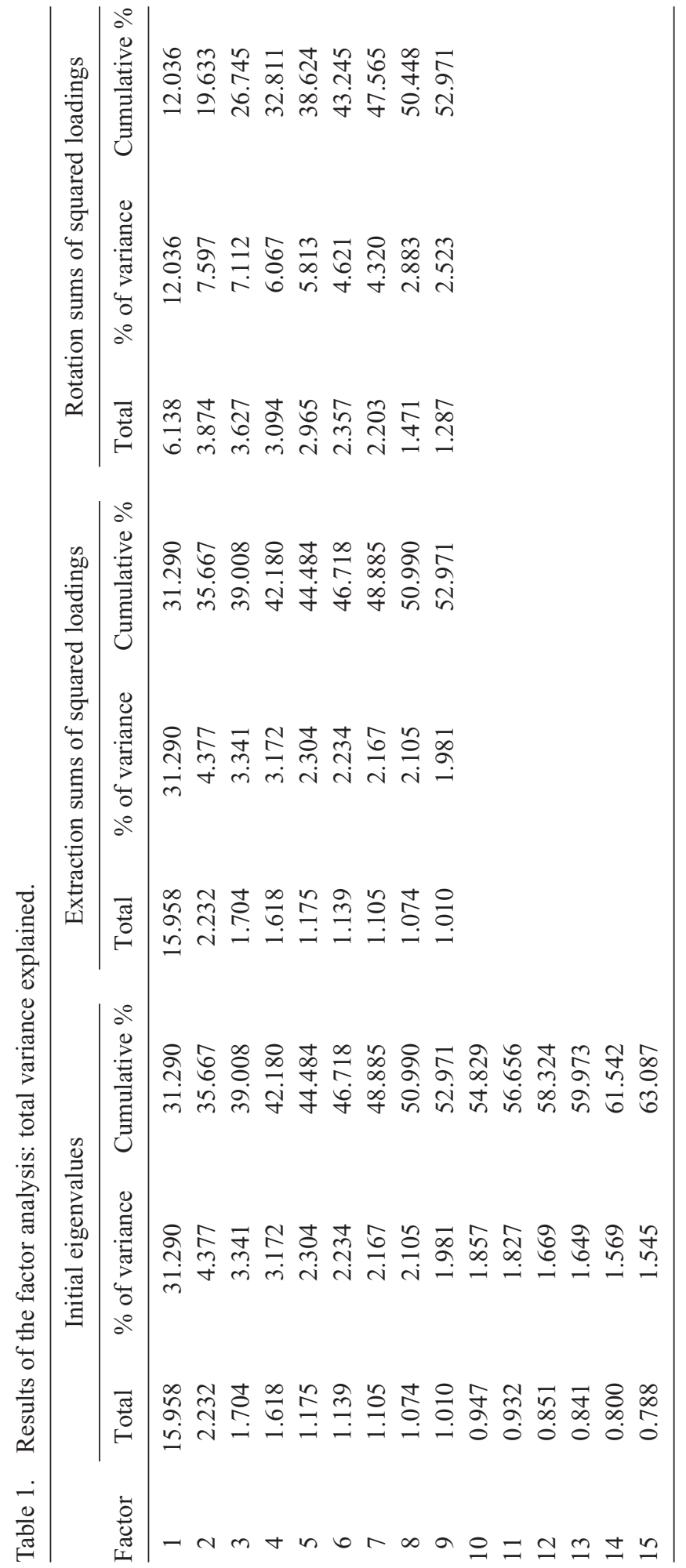


.951 after the problematic items were suppressed. The analysis revealed that nine factors explained $52.971 \%$ of the total variance. The higher the variability explained by the factor analysis, the stronger the factor structure of the scale. However, values ranging from $40 \%$ to $60 \%$ are considered acceptable in social studies (Dunteman 1989). Thus, the variance explained was considered appropriate for the current study. Table 1 illustrates variance explained by each component. Items included in each factor, factor reliability coefficients, means, standard deviations, and varimax rotation loadings are all provided in Table 2.

Table 2. Means, standard deviations, alpha coefficients and varimax rotation loadings.

\begin{tabular}{|c|c|c|c|c|}
\hline \multicolumn{2}{|c|}{ Items and factors } & Mean & SD & $\begin{array}{l}\text { Varimax } \\
\text { factor } \\
\text { load }\end{array}$ \\
\hline \multicolumn{5}{|c|}{ Factor I: Providing support on teaching: $(\alpha=.917)$} \\
\hline 43 & $\begin{array}{l}\text { My cooperating teacher gives feedback to the student } \\
\text { teachers about how to establish classroom discipline }\end{array}$ & 4.322 & 0.817 & 0.644 \\
\hline 27 & $\begin{array}{l}\text { My cooperating teacher guides the student teachers on } \\
\text { how to establish close relationship with the pupils }\end{array}$ & 4.409 & 0.769 & 0.615 \\
\hline 26 & $\begin{array}{l}\text { My cooperating teacher provides suggestions about } \\
\text { effective classroom management techniques to the } \\
\text { student teachers }\end{array}$ & 4.469 & 0.733 & 0.612 \\
\hline 50 & $\begin{array}{l}\text { My cooperating teacher encourages the student teachers } \\
\text { to make their own decisions at the classroom during } \\
\text { teaching practice so that they can gain experience in } \\
\text { deciding which of them are effective and which ones } \\
\text { are not }\end{array}$ & 4.380 & 0.785 & 0.578 \\
\hline 23 & $\begin{array}{l}\text { My cooperating teacher shares with the student teachers } \\
\text { information about the effective methods to use in } \\
\text { establishing classroom discipline }\end{array}$ & 4.290 & 0.833 & 0.560 \\
\hline 51 & $\begin{array}{l}\text { My cooperating teacher encourages the students in } \\
\text { sharing the problems they encounter during their } \\
\text { teaching practice and suggesting solutions to each } \\
\text { other on how to deal with these }\end{array}$ & 4.421 & 0.778 & 0.556 \\
\hline 25 & $\begin{array}{l}\text { My cooperating teacher explains the principles } \\
\text { underlying certain teaching techniques to the student } \\
\text { teachers }\end{array}$ & 4.204 & 0.851 & 0.547 \\
\hline 44 & $\begin{array}{l}\text { My cooperating teacher gives feedback to the student } \\
\text { teachers about how to focus the attention of the pupils } \\
\text { and make them participate in the lesson }\end{array}$ & 4.421 & 0.749 & 0.534 \\
\hline 45 & $\begin{array}{l}\text { My cooperating teacher gives feedback to the student } \\
\text { teachers about how to organise classroom activities } \\
\text { such as pair work and group work }\end{array}$ & 4.245 & 0.826 & 0.501 \\
\hline 42 & $\begin{array}{l}\text { My cooperating teacher gives feedback to the student } \\
\text { teachers about their language skills }\end{array}$ & 4.279 & 0.822 & 0.496 \\
\hline 22 & $\begin{array}{l}\text { My cooperating teacher shares with the student teachers } \\
\text { information about effective teaching methods and } \\
\text { techniques }\end{array}$ & 4.399 & 0.738 & 0.494 \\
\hline 53 & $\begin{array}{l}\text { My cooperating teacher helps the student teachers to be } \\
\text { aware of factors which affected the decisions they } \\
\text { have made during their teaching practice }\end{array}$ & 4.324 & 0.740 & 0.479 \\
\hline
\end{tabular}


Table 2. (Continued).

\begin{tabular}{|c|c|c|c|c|}
\hline \multicolumn{2}{|c|}{ Items and factors } & \multirow{2}{*}{$\begin{array}{l}\text { Mean } \\
4.502\end{array}$} & \multirow{2}{*}{$\frac{\mathrm{SD}}{0.703}$} & \multirow{2}{*}{$\begin{array}{c}\begin{array}{c}\text { Varimax } \\
\text { factor } \\
\text { load }\end{array} \\
0.475\end{array}$} \\
\hline 52 & $\begin{array}{l}\text { My cooperating teacher guides the student teachers in } \\
\text { solving their own problems whenever they encounter } \\
\text { a problem }\end{array}$ & & & \\
\hline 54 & $\begin{array}{l}\text { My cooperating teacher assists the student teachers in } \\
\text { constructing their own teacher identities }\end{array}$ & 4.515 & 0.708 & 0.467 \\
\hline 24 & $\begin{array}{l}\text { My cooperating teacher assists the student teachers to } \\
\text { compare the theory they have been taught at the } \\
\text { university with the ones they have been observing at } \\
\text { the cooperating school }\end{array}$ & 4.199 & 0.828 & 0.463 \\
\hline 21 & $\begin{array}{l}\text { My cooperating teacher demonstrates a variety of } \\
\text { methods and techniques of teaching for the student } \\
\text { teachers }\end{array}$ & 4.313 & 0.778 & 0.405 \\
\hline \multicolumn{5}{|c|}{ Factor II: Orientation to the school/ classroom $(\alpha=.830)$} \\
\hline 13 & $\begin{array}{l}\text { My cooperating teacher gives information to the student } \\
\text { teachers about the physical set up of the school } \\
\text { building (classrooms, labs, gym, café, etc) }\end{array}$ & 3.600 & 1.094 & 0.716 \\
\hline 10 & $\begin{array}{l}\text { My cooperating teacher introduces the student teachers } \\
\text { to administrators, staff, co-teachers and other school } \\
\text { employees }\end{array}$ & 3.860 & 1.040 & 0.683 \\
\hline 18 & $\begin{array}{l}\text { My cooperating teacher invites the student teachers to } \\
\text { the school activities and staff meetings }\end{array}$ & 3.484 & 1.243 & 0.582 \\
\hline 11 & $\begin{array}{l}\text { My cooperating teacher introduces the student teachers } \\
\text { to the pupils in the class }\end{array}$ & 4.181 & 0.955 & 0.570 \\
\hline 12 & $\begin{array}{l}\text { My cooperating teacher shares with the student teachers } \\
\text { information about the interests, skills, and level of } \\
\text { success of the pupils in the class }\end{array}$ & 4.117 & 0.937 & 0.539 \\
\hline 19 & $\begin{array}{l}\text { My cooperating teacher arranges opportunities for the } \\
\text { student teachers to observe other teachers' classrooms }\end{array}$ & 3.164 & 1.316 & 0.537 \\
\hline 15 & $\begin{array}{l}\text { My cooperating teacher shares with the student teachers } \\
\text { information about how to operate and use technical } \\
\text { equipment such as video, OHO, type-recorder, etc }\end{array}$ & 4.079 & 0.951 & 0.475 \\
\hline 14 & $\begin{array}{l}\text { My cooperating teacher gives information to the student } \\
\text { teachers about the rules and policies they are to obey } \\
\text { at the cooperating school }\end{array}$ & 4.254 & 0.872 & 0.465 \\
\hline \multicolumn{5}{|c|}{ Factor III: Providing moral support ( $\alpha=.777)$} \\
\hline 6 & $\begin{array}{l}\text { My cooperating teacher encourages the student teachers } \\
\text { so that they believe in themselves }\end{array}$ & 4.665 & 0.621 & 0.737 \\
\hline 5 & $\begin{array}{l}\text { My cooperating teacher creates a trustful atmosphere so } \\
\text { that the student teachers can share their thoughts } \\
\text { honestly }\end{array}$ & 4.705 & 0.585 & 0.680 \\
\hline 7 & $\begin{array}{l}\text { My cooperating teacher makes the student teachers } \\
\text { believe they are a part of the teaching staff at the } \\
\text { cooperating school }\end{array}$ & 4.562 & 0.679 & 0.664 \\
\hline 8 & $\begin{array}{l}\text { My cooperating teacher encourages the student teachers } \\
\text { when they are discouraged about lesson planning or } \\
\text { teaching a lesson in class }\end{array}$ & 4.602 & 0.643 & 0.626 \\
\hline
\end{tabular}


Table 2. (Continued).

\begin{tabular}{|c|c|c|c|c|}
\hline \multicolumn{2}{|c|}{ Items and factors } & \multirow{2}{*}{$\frac{\text { Mean }}{4.425}$} & \multirow{2}{*}{$\frac{\mathrm{SD}}{0.738}$} & \multirow{2}{*}{$\begin{array}{c}\begin{array}{c}\text { Varimax } \\
\text { factor } \\
\text { load }\end{array} \\
0.423\end{array}$} \\
\hline 9 & $\begin{array}{l}\text { My cooperating teacher creates an atmosphere in which } \\
\text { the student teachers share their ideas and experiences } \\
\text { with each other }\end{array}$ & & & \\
\hline \multicolumn{5}{|c|}{ Factor IV: Providing feedback on lesson planning and teaching performance $(\alpha=.780)$} \\
\hline 38 & $\begin{array}{l}\text { My cooperating teacher gives detailed feedback about } \\
\text { the teaching presentations }\end{array}$ & 4.431 & 0.725 & 0.660 \\
\hline 37 & $\begin{array}{l}\text { Before giving feedback to the student teachers about } \\
\text { their teaching presentation performance, my } \\
\text { cooperating teacher lets them reflect about their own } \\
\text { teaching performance }\end{array}$ & 4.421 & 0.751 & 0.509 \\
\hline 40 & $\begin{array}{l}\text { My cooperating teacher lets the student teachers ask } \\
\text { him/her any kind of questions about the feedback s/he } \\
\text { has provided about their teaching practice } \\
\text { performance }\end{array}$ & 4.523 & 0.674 & 0.460 \\
\hline 29 & $\begin{array}{l}\text { My cooperating teacher checks the lesson plans of the } \\
\text { student teachers and gives feedback before they teach } \\
\text { the class }\end{array}$ & 4.586 & 0.689 & 0.445 \\
\hline 41 & $\begin{array}{l}\text { After my cooperating teacher teaches a lesson, s/he } \\
\text { reflects on his/her teaching performance so that the } \\
\text { student teachers can use him/her as a model when they } \\
\text { are reflecting their own teaching practice performance }\end{array}$ & 4.265 & 0.802 & 0.432 \\
\hline 30 & $\begin{array}{l}\text { My cooperating teacher checks the lesson plans of the } \\
\text { student teachers again in order to see whether they } \\
\text { have edited their lesson plans according to the prior } \\
\text { feedback }\end{array}$ & 4.496 & 0.738 & 0.425 \\
\hline \multicolumn{5}{|c|}{ Factor V: Guidance about resources for teaching $(\alpha=.657)$} \\
\hline 16 & $\begin{array}{l}\text { My cooperating teacher guides the student teachers to } \\
\text { reach sources such as reference books, professional } \\
\text { magazines }\end{array}$ & 4.290 & 0.862 & 0.640 \\
\hline 28 & $\begin{array}{l}\text { My cooperating teacher assists the student teachers to } \\
\text { reach necessary sources during their lesson } \\
\text { preparations }\end{array}$ & 4.313 & 0.835 & 0.576 \\
\hline 20 & $\begin{array}{l}\text { My cooperating teacher shares with the student teachers } \\
\text { information about the curriculum }\end{array}$ & 4.444 & 0.769 & 0.464 \\
\hline \multicolumn{5}{|c|}{ Factor VI: Evaluation $(\alpha=.574)$} \\
\hline 47 & $\begin{array}{l}\text { My cooperating teacher evaluates the files of the student } \\
\text { teachers periodically }\end{array}$ & 4.494 & 0.748 & 0.653 \\
\hline 46 & $\begin{array}{l}\text { My cooperating teacher keeps a file of observation and } \\
\text { evaluation forms for each of the student teachers }\end{array}$ & 4.670 & 0.635 & 0.602 \\
\hline 48 & $\begin{array}{l}\text { While evaluating the student teachers, my cooperating } \\
\text { teacher takes into consideration of the progress during } \\
\text { the practicum }\end{array}$ & 4.580 & 0.653 & 0.513 \\
\hline \multicolumn{5}{|c|}{ Factor VII: Self-preparation for the mentor role $(\alpha=.688)$} \\
\hline 3 & $\begin{array}{l}\text { My cooperating teacher interacts with other cooperating } \\
\text { teachers who mentor other distance student teachers }\end{array}$ & 4.493 & 0.692 & 0.656 \\
\hline
\end{tabular}


Table 2. (Continued).

\begin{tabular}{|c|c|c|c|c|}
\hline \multicolumn{2}{|c|}{ Items and factors } & \multirow{2}{*}{$\begin{array}{l}\text { Mean } \\
4.341\end{array}$} & \multirow{2}{*}{$\begin{array}{c}\text { SD } \\
0.747\end{array}$} & \multirow{2}{*}{$\begin{array}{c}\begin{array}{c}\text { Varimax } \\
\text { factor } \\
\text { load }\end{array} \\
0.598\end{array}$} \\
\hline 2 & $\begin{array}{l}\text { My cooperating teacher interacts with the cooperating } \\
\text { school coordinator during the practicum }\end{array}$ & & & \\
\hline 4 & $\begin{array}{l}\text { My cooperating teacher investigates other sources to } \\
\text { gain information about the responsibilities of a } \\
\text { cooperating teacher during the practicum }\end{array}$ & 4.163 & 0.802 & 0.595 \\
\hline 1 & $\begin{array}{l}\text { My cooperating teacher reads the guide book about the } \\
\text { teaching practicum which university prepared for the } \\
\text { student teachers and cooperating teachers }\end{array}$ & 4.484 & 0.683 & 0.562 \\
\hline \multicolumn{5}{|c|}{ Factor VIII: Providing feedback on observation forms $(\alpha=.562)$} \\
\hline 35 & $\begin{array}{l}\text { My cooperating teacher gives the completed } \\
\text { observation/evaluation forms to the student teachers }\end{array}$ & 4.218 & 1.084 & 0.640 \\
\hline 36 & $\begin{array}{l}\text { My cooperating teacher explains to the student teachers } \\
\text { how to make use of the completed observation and } \\
\text { evaluation forms }\end{array}$ & 4.441 & 0.818 & 0.461 \\
\hline \multicolumn{5}{|c|}{ Factor IX: Providing written feedback $(\alpha=.413)$} \\
\hline 33 & $\begin{array}{l}\text { My cooperating teacher fills in observation and } \\
\text { evaluation forms for each student teacher each time } \\
\text { they teach in the classroom }\end{array}$ & 4.642 & 0.769 & 0.643 \\
\hline 32 & $\begin{array}{l}\text { My cooperating teacher takes notes while the student } \\
\text { teachers are teaching }\end{array}$ & 4.474 & 0.752 & 0.430 \\
\hline
\end{tabular}

In Table 2, it is common to see some factors with alpha values lower than .70 because there were very few indicators in those factors. This situation does not mean that those factors were unreliable. As suggested by Pallant (2001), if a measurement construct has less than ten items, it is usual to see low alpha values. In these situations, corrected-item total correlations should be checked to be sure about the quality of the items within a specific factor. As mentioned before, items with low corrected-item total values were already removed from the analysis. Corrected-item total values of current items in the scale ranged between .378 and .601 , which meant that the reliability assumptions were met.

In summary, the analysis indicated that the Cronbach alpha value of the MTRI was 0.951. Also, the principal component analysis with nine factors and 49 indicators explained $52.971 \%$ of the total variance, which shows that the MTRI is a very valid and reliable instrument.

\section{Discussion}

Below, each subscale of MTRI is discussed in relation to Hudson's five-factor model and also other conceptualisations of mentoring dimensions in related literature.

The first factor consisted of items related to classroom management strategies, theory and methods of teaching, organising classroom activities, instructional strategies, decision and making. Therefore, the first subscale is named 'Providing support on teaching'. This subscale of MTRI represents a similar aspect with 'pedagogical knowledge' dimension of Hudson's mentoring model. Also, it taps a similar content 
domain as Demirkol's (2004) and Shippy's (1989) 'Sharing the knowledge of teaching' subscale: 'My co-operating teacher explains the principles underlying certain teaching techniques to the student teachers', 'My co-operating teacher guides the student teachers on how to establish close relationship with the pupils', 'My co-operating teacher shares the information about the effective teaching methods and techniques with the student teachers', 'My co-operating teacher provides the student teachers with suggestions about effective classroom management techniques'. Hence, the 'Providing support on teaching' subscale of MTRI is more informative and covers a variety of topics in relation to effective teacher characteristics also defined in related literature. For example, the following are characteristics of an effective teacher: being a good classroom manager (Creemers and Reezigt 1896; Doyle 1986; Giovanelli 2003; Quaglia and Russel 1989; Witcher, Onweugbuzie, and Minor 2001), establishing a good rapport with pupils (Brown and McIntyre 1993), using varied effective methods and instructional techniques (Demmon-Berger 1986; Haigh and Katerns 1984; Witcher et al. 2001), engaging learners on task (Crocker 1986), promoting active student participation (Minor et al. 2002), promoting critical and creative thinking (Minor et al. 2002), dealing with student misbehaviours (Crocker 1986), promoting group work activities (Borich 1992), having good pedagogical knowledge (Medwell et al.1999) and making professional decisions (Medley 1979). This factor is the most important one. It explains $31.2 \%$ of the total variance of the whole MTRI, which indicates that according to student teachers the major responsibility of a mentor is to help them gain effective teaching strategies and prepare them to be effective teachers.

Items concerning the physical setup of the co-operating school, rules of the school building, school activities, school staff and the learners in the class are gathered under the subscale 'Orientation to the school/classroom'. This is the second most important factor explaining $4.3 \%$ of the total inventory. The 'Orientation to the school $/$ classroom' subscale overlaps with 'System requirements' dimension of Hudson's model (2004). Hudson and Skamp (2001, 2003) claim that teaching curriculum and school policies are fundamental to effective teaching and therefore co-operating teachers need to be familiar with the current system to orient the student teachers about how to implement requirements in the school. The subscale also overlaps with the 'Orientation to the school/classroom' subscales of both Shippy (1989) and Demirkol (2004). Brooks and Sikes (1997) also consider 'Orientation of student teachers' to be one of the responsibilities of the co-operating teacher. Co-operating teachers provide students with information about the school, introduce them to the teaching staff, draw attention to policies and rules, and outline expectations about professional involvement (e.g., meetings).

According to Hudson's mentor model (2004) 'feedback' is an important function of a mentor. In the present study items about mentor's feedback are clustered under three subscales. These three subscales of the MTRI are: 'Providing feedback on lesson planning and teaching performance' (factor IV), 'providing written feedback' (factor IX) and 'providing feedback on observation forms' (factor XIII). In Factor IV, items constitute statements about oral feedback. For example Item 37 states 'Before giving feedback to the student teachers about their teaching presentation performance, the cooperating teacher lets them reflect about their teaching performance'. Similarly, Item 40 states 'My co-operating teacher lets the student teachers as him/her any questions about the feedback she/he has provided them about their teaching practice'. On the contrary Factors VIII and IX cover items related to written feedback. For example 
Item 33 states 'My co-operating teacher fills in observation form for each student teacher each time they teach'. Similarly item 32 states 'My co-operating teacher takes notes while the student teachers are teaching'. Therefore, an important finding of the study is that the present study recognises 'feedback' role as three consistent functions, thereby according it entirely three interconnected categories.

Learning and successful supervision require effective feedback that the mentor must provide (Moberg 2008). Because feedback enables the mentor to constructively assist the mentee's development as a teacher, it is a crucial component of the mentoring process (Bellm, Whitebook, and Hnatiuk 1997; Fish 1995; Haney 1997; Bishop 2001). It is interesting that despite the highlighted importance of feedback; the two interrelated subscales of the MTRI ('providing feedback on observation and evaluation forms' and 'providing written feedback') are among the least perceived mentor functions. This may be due to the fact that in Turkey the mentors do not get special training associated with their supervisory work. In DETTP, the mentors are the only providers of feedback to their student teachers. However, the mentors are not trained about how to provide the student teachers with effective feedback. In the DETTP mentors are required to fill out the observation forms and return them to the student teachers for their professional development. However, since the mentors do not get any special training about the aim and importance of written feedback, they are likely to perceive it as 'a paper work'. Therefore, it is possible that the student teachers at the DETTP did not regard such feedback as helpful and were not satisfied with the written feedback on these forms since they were not constructive. Supporting this assertion, Wilkins-Canter (1997) found that the feedback of co-operating teachers who are not trained to give specific feedback was not effective. In the same line, Knowles and Cole (1996) indicate that co-operating teachers who do not receive a professional preparation for their work fail to fulfill some of their basic mentor roles.

One of the most perceived mentor roles was 'Providing moral support'. The MTRI's subscale 'Providing moral support' consists of items such as 'My co-operating teacher encourages the student teachers so that they believe in themselves', 'My co-operating teacher creates a trustful atmosphere so that the student teachers can share their thoughts honestly' and 'My co-operating teacher creates an atmosphere in which the student teachers share their ideas and experiences with each other'. 'Providing moral support' subscale of the MTRI is associated with the 'Personal attributes' dimension of Hudson's model of mentor. Each of the items in the subscale represents the moral aspect of mentoring. Emotional support is one of the basic components of mentoring (Little 1990). Similarly, Wildman et al. (1992) identify praise and encouragement as supportive behaviours. Arends (1998) and Portner (2001) posit that emotional support (i.e., the feeling of belonging, a sense of confidence, self-sufficiency and a safe environment) is necessary in the beginning. Likewise, Gold (1996) defines psychological support as related to nurturing the mentee's self-esteem, confidence, and development of feelings of effectiveness.

Another subscale consists of four items which reflects co-operating teachers' self attempt to gain understanding of the role of a mentor to fulfill that role (Table 2). Therefore, the subscale is named 'Self-preparation for the mentor role'. 'Preparation' is a starting point for an effective mentoring relationship and requires self-preparation to get ready to assist the mentee and gather information about the mentee's background and needs (Zachary 2000). 'Self-preparation' subscale of the MTRI is neither included in Hudson's model of mentor, nor in other conceptualisations of mentoring 
dimensions in literature. This could be explained by the fact that the co-operating teachers in Turkey do not get any specific training about their mentor roles prior to field experience. Similarly, Podsen and Denmark (2000) indicate that co-operating teachers have little experience with the key activities associated with the mentoring process-observing, discussing, and providing specific feedback on performance (10).

Another explanation, in part, may be due to the nonexistence of a regular university supervisor. During the field experience period, student teachers are mentored only by a co-operating teacher and do not get regular university supervisor support. The university supervisor also acts as a bridge between the faculty and the co-operating school, and the co-operating teacher. Absence of the university supervisors is likely to lead to lack of communication among these and terminate the co-operating teachers' opportunity to share their problems and get guidance from the university supervisor about the mentorship. A handbook about the practicum process prepared by the university is the only practical source for the co-operating teachers. Therefore, it is possible that the mentors of the distance student teachers may not feel themselves ready for their roles as mentors and in order to gain more information about how to mentor the student teachers they may be in need of interacting with other mentors of distance student teachers and the programme coordinator at the co-operating school, and investigate other sources than the handbook.

Assessment and completion of a record of professional accomplishments are also the responsibilities of a co-operating teacher (Brooks and Sikes 1997, 48). Hudson (2004) does not include this function of the mentor in his mentor model. Similarly, prior studies do not identify this category as a distinct function of a mentor (Demirkol 2004; Shippy 1989). Notably, the present study documented 'evaluation' as a distinct characteristic of the mentor role. This shows that the distance student teachers are likely to feel 'evaluation' as a part of their mentoring responsibility. However, intriguingly the MTRI's subscale 'evaluation' was one of the least perceived mentor roles by student teachers, which means that the student teachers do not regard mentor roles associated with evaluation as the primary responsibility of co-operating teachers. This may be due to the student teachers' concern for being criticised for their teaching practice. Disciplinary literature also supports this assumption. Al-Khataybeh (2002) who investigated the student teachers' perceptions associated with their co-operating teachers' roles found that the role of an 'evaluator' was regarded as the second least effective role of a co-operating teacher.

\section{Conclusion}

The primary purpose of the present study is to construct and validate an inventory for the mentor roles during distance practicum. Therefore, an imperative implication of the present study is that a reliable and valid Mentor Teacher Role Inventory is constructed. The analysis of the MTRI yielded mentor dimensions similar to those reported in previous literature increasing the confidence in the stability of these mentor roles. The study is important because it is the first attempt in Turkey to investigate the mentor roles during distance practicum from the perspective of the student teachers.

The study is also noteworthy in that it has provided the distance ELT student teachers with the opportunity to voice their thoughts about the mentor roles of the cooperating teachers. Another significance of this study is to further develop research, in conjunction with the results of the initial study (Koc 2008), on comparing and 
contrasting the cooperating teachers' and student teachers' perceptions on mentoring roles. The findings of such a study could well inspire discussions on the possible grounds of the different perceptions on mentor roles between the two groups.

It may be difficult for the distance teacher training organisers to ensure that a mentor fulfills the required responsibilities. Findings from the use of the MTRI might stimulate discussions on whether the mentors execute all the requirements of their responsibilities with competency. Accordingly, it can serve as an instrument for reflection that may offer the programme co-coordinators some ideas for promoting mentor-training programmes prior to distance practicum to enhance the supervisory process and implementation of the programme. Furthermore, the MTRI might also serve as a template for developing similar tools for evaluating the mentoring process.

Further research aimed at adapting the MTRI to both the traditional pre-service and in-service teacher education contexts could develop a shared notion of 'mentoring' in these interrelated contexts and maximise its application in the teacher education context.

\section{Notes on contributor}

Ebru Melek Koç holds a PhD in the field of English language teaching (ELT). Currently she works at the Izmir Institute of Technology, in the Department of Foreign Languages. Her areas of research are pre/in-service teacher education and development, distance teacher training, and teaching English as a foreign language.

\section{References}

Al-Khataybeh, M. 2002. English language cooperative teachers' roles as perceived by student teachers. Umm Al-Quora University Journal 14, no. 1: 7-22.

Anderson, E.M., and A.L. Shannon. 1988. Towards a conceptualization of mentoring. Journal of Teacher Education 39, no. 1: 38-42.

Arends, R.I. 1998. Teacher induction: Research and examples of contemporary practice. Paper presented at the Suncoast Academy for Teacher Induction, Pinella County Schools, in Largo, FL.

Barab, S.A. and K.E. Hay. 2001. Doing science at the elbows of experts: Issues related to the science apprenticeship camp. Journal of Research in Science Teaching 38, no. 1: 70-102.

Bellm, D., M. Whitebook, and P. Hnatiuk. 1997. The early childhood mentoring curriculum: Trainer's guide. Washington, DC: National Center for the Early Childhood Work Force.

Bishop, C. 2001. Case-based learning and the construction of professional practical knowledge in teacher education. Unpublished diss., University of Sydney.

Borich, G.D. 1992. Effective teaching methods. New York: MacMillan.

Brooks, V., and P. Sikes. 1997. The good mentor guide: Initial teacher education in secondary schools. Buckingham: Open University Press.

Brown, S., and D. McIntyre. 1993. Making sense of teaching. Buckingham: Open University Press.

Clawson, J.G. 1980. Mentoring in managerial careers. In Work, family and the career: New frontiers in theory and research, ed. C.B. Derr, 144-65. New York: Praeger

Comrey, A.L., and H.B. Lee. 1992. A first course in factor analysis. Hillsdale, NJ: Erlbaum.

Coombs, W., and H. Schroeder. 1988. An analysis of factor analytic data. Personality and Individual Differences 9: 79-85.

Creemers, B.P.M., and G.J. Reezigt. 1996. School level conditions affecting the effectiveness of instruction. School Effectiveness and School Improvement 7: 197-228.

Crocker, R. 1986. What research says to the teacher: Classroom processes and student outcomes. (ERIC Reproduction Service No. ED2777095.) 
Demirkol, I. 2004. Expectations for the roles of co-operating teachers and university supervisors during the practice teaching period as perceived by university supervisors, co-operating teachers and student teachers. Unpublished diss., Boğaziçi University, Istanbul.

Demmon-Berger, D. 1986. Effective teaching: Observations from research. Arlington, VA: American Association of School Administrators.

Doyle, W. 1986. Classroom organization and management. In Handbook of research on teaching, ed. M.C. Wittrock, 392-431. New York: MacMillan

Dunteman, G.H. 1989. Principal component analysis: Quantitative applications in the social sciences series (vol. 69). Thousand Oaks, CA: Sage Publications.

Giovanelli, M. 2003. Relationship between reflective disposition toward teaching and effective teaching. Journal of Educational Research 96, no. 5: 293-330.

Gold, Y. 1996. Beginning teacher support: Attrition, mentoring, and induction. In Handbook of research on teacher education, ed. J. Sikula, T. Buttery, and E. Guyton, 548-94. New York: Macmillan Library Reference.

Field, A. 2000. Discovering statistics using SPSS for windows. London: Sage Publications.

Fish, D. 1995. Quality mentoring for student teachers. London: David Fulton.

Haigh, N., and B. Katterns. 1984. Teacher effectiveness: Problem or goal for teacher education. Journal of Teacher Education 35: 23-7.

Hall, K.M., R.J. Draper, L.K. Smith, and R.V. Bullough. 2008. More than a place to teach: Exploring the perceptions of the roles and responsibilities of mentor teachers. Mentoring and Tutoring: Partnership in Learning 16, no. 3: 328-45.

Hall, K.M., L.K. Smith, R.J. Draper, R.V. Bullough, and R. Sudweeks. 2005. Measuring the self-efficacy of mentor teachers. Academic Exchange Quarterly 9, no. 4: 188-92.

Haney, A. 1997 The role of mentorship in the workplace. In Work place education, ed. M.C. Taylor, 211-28. Toronto: Culture Concepts.

Hudson, P. 2004. Mentoring for effective primary science teaching. Unpublished diss., Queensland University of Technology, Brisbane.

Hudson, P., and K. Skamp. 2001. Mentoring pre-service teachers of primary science. Paper presented at the Science Teachers' Association of Ontario Conference, in Toronto.

Hudson, P., and K. Skamp. 2003. Mentoring pre-service teachers of primary science. The Electronic Journal of Science Education 7, no. 1. http://unr.edu/homepage/jcannon/ejse/ ejse.html

Hudson, P., K. Skamp, and L. Brooks. 2005. Development of an instrument: Mentoring for effective primary science teaching. Science Education 89, no. 4: 657-74.

Hutcheson, G., and N. Sofroniou. 1999. The multivariate social scientist. London: Sage.

Kass, R.A., and H.E.A. Tinsley. 1979. Factor analysis. Journal of Leisure Research 11: 120-38.

Knowles, G.J., and A.L. Cole. 1996. Developing practice through field experiences. In The teacher educator's handbook: Building a knowledge base for the preparation of teachers, ed. F.B. Murray, 648-88. San Francisco: Jossey-Bass.

Koc, E.M. 2008. An investigation of co-operating teachers' roles as mentors during the teaching practicum at distance BA program in ELT at Anadolu University Open Education Faculty. Unpublished diss., Anadolu University, Eskiehir.

Little, J.W. 1990. The mentor phenomenon and the social organization of teaching. Review of Research in Education 16: 297-351.

Medley, D. 1979. The effectiveness of teachers. In Research on teaching: Concepts, findings and implications, ed. P. Peterson, and H. Walberg, 15-34. Berkeley, CA: McCutchan.

Medwell, J., D. Wray, L. Poulson, and R. Fox. 1999. The characteristics of effective teachers of literacy. Education 27, no. 1: 46-52.

Merriam, S. 1983. Mentors and protégés: A critical review of the literature. Adult Education Quarterly 33: 161-73.

Minor, L.C., A.J. Onwuegbuzie, A.E. Witcher, and T.L. James. 2002. Preservice teachers' educational beliefs and their perceptions of characteristics of effective teachers. Journal of Educational Research 96, no. 2: 116-27.

Moberg, D.J. 2008. Mentoring for protégé character development. Mentoring and Tutoring: Partnership in Learning 16, no. 19: 91-103.

Pallant, J. 2001. SPSS survival manual. Maidenhead, PA: Open University Press. 
Podsen, I.J., and V.M. Denmark. 2000. Coaching and mentoring first-year and student teachers. New York: Eye on Education.

Portner, H. 2001. Training mentors is not enough. Thousand Oaks, CA: Corwin.

Quaglia, R. 1989. Socialization of the beginning teacher: A theoretical model from the empirical literature. Research in Rural Education 5, no. 3: 1-7.

Rose, G.L. 2003. Enhancement of mentor selection using the ideal mentor scale. Research in Higher Education 44, no. 4: 473-94.

Shippy, V.S. 1989. An investigation of role expectations in the student teaching triad as viewed by student teachers, co-operating teachers and college supervisors. Unpublished diss., State University of New York, Albany.

Tabachnick, B.G., and L.S. Fidell. 1996. Using multivariate statistics. New York: Harper and Row.

Teprongtong, S. 1984. Role expectations and the role performance of college supervisors on student teaching as perceived by school principles, co-operating teachers and student teachers. Unpublished diss., Pan University.

Tullis, R.J. 1988. Expectation shift of student teachers and their co-operating teachers. Unpublished diss., Texas University.

Wildman, T.M., S.G. Magliaro, R.A. Niles, and J.A. Niles. 1992. Teacher mentoring: An analysis of roles, activities and conditions. Journal of Teacher Education 43, no. 3: 205-13.

Wilkins-Canter, E.A. 1997. The nature and effectiveness of feedback given by co-operating teachers to student teachers. The Teacher Educator 31, no. 4: 235-49.

Witcher, A.E., A.J. Onwuegbuzie, and L.C. Minor. 2001. Characteristics of effective teachers: Perceptions of pre-service teachers. Research in the Schools 8: 45-57.

Zachary, L.J. 2000. The mentor's guide: Facilitating effective learning relationships. San Francisco: Jossey-Bass.

Zanting, A., N. Verloop, and J.D. Vermunt. 2001. Student teachers' beliefs about mentoring and learning to teach during teaching practice. British Journal of Educational Psychology 71: $57-80$. 